Available online on 15.07.2018 at http://jddtonline.info
Open Access to Pharmaceutical and Medical Research
commercial use, provided the original work is properly cited

Open $\odot$ Access

Research Article

\title{
In-vitro study on the hemolytic activity of different extracts of Indian medicinal plant Croton bonplandianum with phytochemical estimation: a new era in drug development
}

\author{
*Tanmay Ghosh ${ }^{1}$, M. K. Biswas ${ }^{2}$, Sandipan Chatterjee ${ }^{3}$, Pradipta Roy ${ }^{1}$ \\ ${ }^{1}$ Department of Microbiology, Rabindra Mahavidyalaya, Champadanga, Hooghly, W.B., India \\ 2 Department of Plant Protections, Palli Siksha Bhavana, Visva-Bharati, Sriniketan, Birbhum, W.B., India \\ ${ }^{3}$ Department of Botany, Suri Vidyasagar College, Suri, Birbhum-731101, West Bengal, India
}

\section{ABSTRACT}

In this study different extracts of the leaves of Croton bonplandianum were screened for the haemolytic activity towards human erythrocytes. The haemolytic activity was performed by modified spectroscopic method at four different concentrations $(300,150$, $75,25 \mu \mathrm{g} / \mathrm{ml}$ ). The haemolytic activity of the different extracts of Croton bonplandianum was found in the following order Ethyl acetate extract > Chloroform extract > Benzene extract. However, all the extracts alone and in combination with each other exhibited very low haemolytic activity. Hence, they can be considered as safe to human erythrocytes.

Keywords: Hemolytic activity, Croton bonplandianum, Erythrocytes

Article Info: Received 14 March, 2018; Review Completed 04 June 2018; Accepted 06 June 2018; Available online 15 July 2018

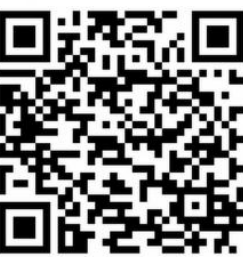

\section{Cite this article as:}

Ghosh T, Biswas MK, Chatterjee S, Roy P, In-vitro study on the hemolytic activity of different extracts of Indian medicinal plant Croton bonplandianum with phytochemical estimation: a new era in drug development, Journal of Drug Delivery and Therapeutics. 2018; 8(4):155-160 DOI: http://dx.doi.org/10.22270/jddt.v8i4.1747

*Address for Correspondence:

Tanmay Ghosh, Department of Microbiology, Rabindra Mahavidyalaya, Champadanga, Hooghly, W.B., India

\section{INTRODUCTION}

Medicinal plants are the rich source of medicinally important compounds and since ancient time, plants and plant derived products are used as medicine in traditional and folk medicinal system. Initially the herbal drugs were used in the form of dried powder, gums, extracts or formulations of more than one plant products. Advanced scientific techniques brought a revaluation in herbal medicine industry and all focus is concentrate on active principles (bioactive molecule). However, a lot of processing is required to develop a drug from the natural sources. Toxicity of the active molecule is a key factor during drug designing, and hemolytic activity represents a useful starting point in this regard, it provides the primary information on the interaction between molecules and biological entities at cellular level. Hemolytic activity of any compounds is an indicator of general cytotoxicity towards normal healthy cells (Da Silva et al., 2004). Certain conditions may influence to complicate SSTIs such as trauma, pre-existing skin conditions, diabetes mellitus, or immune suppression $\mathbf{1 , 2}$. SSTIs in hospitalized patients are associate with considerable patient morbidity, mortality and escalating healthcare expenditures, because of the need for additional surgery, antimicrobial therapy and prolonged hospital stay ${ }^{3}$.One of such with promising medicinal principle is Croton bonplandianum, a member of the family Euphorbiaceae is an exotic weed commonly found in the waste lands and commonly known as 'Bantulsi' in Bengali and "Kukka tulsi" in Telugu ". The leaf of $C$. bonplandianum is used in the treatment of skin diseases, cuts and wounds have been claimed as antiseptic in nature 5 . This species of Croton is considered as chologogue and purgative ${ }^{\mathbf{6}}$. The plant is reported to possess potent hepatoprotective and antihelmenthic properties ${ }^{7}$. Leaves of this exotic weed are highly medicinal and used for controlling high blood pressure $^{8}$ and the leaves infusion is used to cure fever 
caused due to infection of glands ${ }^{9}$. Latex of the plant has wound healing activity ${ }^{\mathbf{1 0}, 11}$ and the fresh juice of the leaves is used against headache ${ }^{\mathbf{1 2}}$. The seed of Croton bonplandianum contains diterpines, phorbolester, including 12-orthotrideconeoly-phorbol-13-acetate (TPA) and myristoyl phorbol acetate (MPA). TPA is a carcinogen, affecting prostaglandin metabolism ${ }^{13,14}$. The fresh juice of the plant is used against head ache byethnic groups. Latex of plants has healing effect on wounds and cuts ${ }^{\mathbf{1 5 , 1 6}}$. the present paper deals with the investigation of different types of phytochemicals qualitatively and quantitatively such as tannin, phlobatannin, terpenoid, glycoside, phenolic, flavonoid, steroid, anthraquinone, saponin, alkaloid, cholesterol, carbohydrate and protein for a clear understanding regarding the phytochemical status of the stem of $C$. bonplandianus which may help future investigators in their Pharmacological analysis of this species.

\section{Phytochemical aspects of Plant extract (Croton bonplandianum):}

The genus Croton contains diverse types of biomolecules. Terpenoids are the predominant secondary metabolite constituents in the genus, chiefly diterpenoids, which may belong to the cembranoid, clerodane, neoclerodane, halimane, isopimarane, kaurane, secokaurane, labdane, phorbol and trachylobane skeletal types. Triterpenoids, either pentacyclic or steroidal, have frequently been reported from Croton species. Volatile oils containing mono and sesquiterpenoids, and sometimes also shikimate-derived compounds are not rare in the genus. Several species have been reported as sources of different classes of alkaloids, a fact that enhances considerably the importance of the genus from the medicinal point of view. Phenolic substances have frequently been reported, among which flavonoids, lignoids and proanthocyanidins predominate. (Salatino et al., 2007) Several species of Croton, containing proanthocyanidins and/or alkaloids have a red sap. The latter may be taspine or some of several benzyl isoquinoline like compounds. Diterpenes are very common in Croton, corresponding to clerodanes, cembranoid, halimanes, kauranes, labdanes, phorbol esters, trachylobanes and sarcopetalanes. Some species are aromatic due to the possession of volatile oils. Representatives of new classes of compounds (phenylbutanoids, glutarimide alkaloids, sarcopetalane diterpenes) have been isolated from Croton species. While laticifers have been described in Croton species, so far there are no anatomical studies about secretory structures of volatile oil. Few studies about flavonoids have been carried out with Croton species. Chemical affinities are apparent in the genus, grouping species with (i) kauranes and/or labdanes, (ii) trachylobanes and (iii) alkaloids. Pharmacological assays have frequently corroborated the traditional uses of Croton species. A great part of pharmacological assays with Croton substances dealt with the clerodane transdehydrocrotonin. (Salatino et al., 2007) In 2010 A new flavone, named crotoncaudatin, was isolated from the stems of Croton bonplandianum Geisel. var. tomentosus Hook., together with nine known analogues: 3,5,6,7,8,3', $4^{\prime}$-heptamethoxyflavone, tangeretin, nobiletin, 5,6,7,4'-tetramethoxy-flavone, sinensetin, kaempferol, tiliroside, kaempferol-3-O-rutinoside and rutin. (Zou et al., 2010) Ethanol extract of the leaves of Croton steenkampianus contains a indanone derivative and two diterpenoids together with three flavonoids. (Adeboye et al., 2008) Some antimicrobial compounds like acetyl aleuritolic acid, stigmasterol, $\beta$ - sitosterol, campesterol, $\quad \beta$-sitosterol- $O$-glucoside, $\quad$ sonderianin, catechin and gallocatechin was isolated from methanolic extract of Croton urucuruna. (Marize et al., 1997) Phytochemically the plant has been reported to contain Rutin (C18 H36 O19) as main constituent together with crotsparinine, crotosparine and its methyl derivatives aphorbol which play a key role in wound healing. (Divya et al., 2011) Apart from these Croton bonplandianum is a good source of Steroids, Unsaturated steroids, Phenolics, Alkaloids. It also contains Flavons and flavonols, Cardinolids, Leuco antho -cyanin and Flavonoids. (Kothale et al., 2011). The plant also contains another two groups of compounds viz. Terpenoids and Glycosides along with flavonoids and alkaloids. The spent residue obtained after biocrude extraction of Croton bonplandianum is rich in biopolymers, such as cellulose, hemicellulose and lignin. Oil and ethanol can be obtained from this. (Sharma et al., 1990) Jeeshna et al., (2011) studied on the potentiality of different solvent to extract different group of compound from Croton bonplandianum and they showed Methanol was much more effective to extract Alkaloids, Flavonoids, Glycosides, Steroids, Phenols, Tannins, Saponins and Resins followed by Acetone, Chloroform and Petroleum ether. Although chloroform fraction does not contain alkaloids and saponins. ( Jeeshna et al., 2011) Some isolated triterpenoid from the root of $C$. bonplandianum are 3hydroxyurs- 12,15-dien of ursane skeleton, oleanolic acid, ursolic acid and sitosterol. (Ghosh et al., 2013). Alkaloid isolated from extracts of Croton bonplandianum 3-methoxy-4,6dihydroxymorphinandien-7-one, and norsinoacutine.( Tiwar et al.,1981)

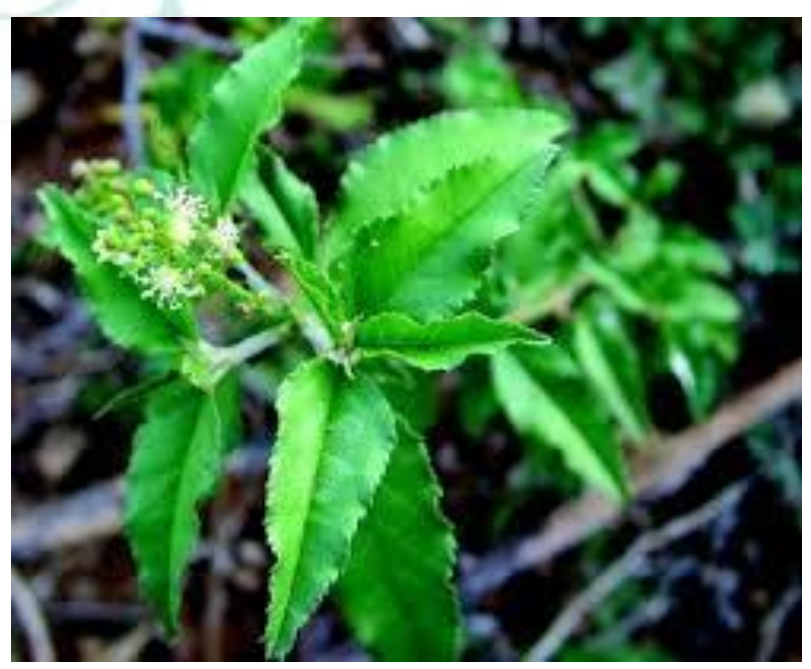

MATERIALS AND METHOD

\section{Collection of Plant:}

The plant Croton bonplandianum is collected from the rural area of Champadanga ( Champadanga, Hooghly) 
Taxonomical Position of Croton bonplandianum:

Kingdom: Plantae

Subkingdom: Tracheobionta

Infrakingdom: Streptophyta

Superdivision: Spermatophyta

Division: Magnoliophyta

Class: Magnoliopsida

Subclass: Rosidae

Order: Malpighiales

Family: Euphorbiaceae

Subfamily: Crotonoideae

Tribe: Crotoneae

Genus: Croton

Species: Croton bonplandianum

\section{Preparation of Plant extract:}

At first the plant part (leaf) was washed with distilled water, dried in shade, grinded to fine powder and stored in airtight containers at room temperature in dark until used. The powdered samples were subjected to extraction by the following method of Gupta et al. (2009).

\section{Chloroform Extraction:}

$5 \mathrm{~g}$ of air dried powder of Croton bonplandianum leaf extract was mixed with $25 \mathrm{ml}$ Chloroform to obtain a final concentration of $100 \mathrm{mg} / \mathrm{ml}$. Each solution was stored at $4{ }^{\circ} \mathrm{C}$ after collecting in sterilized glass tubes until use.

\section{Ethyl Acetate Extraction:}

$5 \mathrm{~g}$ of air dried powder of Croton bonplandianum leaf extract was mixed with $25 \mathrm{ml}$ Ethyl Acetate to obtain a final concentration of $100 \mathrm{mg} / \mathrm{ml}$. Each solution was stored at $4^{\circ} \mathrm{C}$ after collecting in sterilized glass tubes until use.

\section{Benzene Extraction:}

$5 \mathrm{~g}$ of air dried powder of Croton bonplandianum leaf extract was mixed with $25 \mathrm{ml}$ organic Benzene to obtain a final concentration of $100 \mathrm{mg} / \mathrm{ml}$. Each solution was stored at $4^{\circ} \mathrm{C}$ after collecting in sterilized glass tubes until use.

\section{Preparation of erythrocytes suspension:}

Two millilitres of blood was collected from a healthy individual (blood group B positive) in a tube containing heparin. The blood was centrifuged at $1500 \mathrm{rpm}$ for three minutes in a laboratory centrifuge.

\section{Phytochemical Determination:}

\section{Extract preparation:}

$20 \mathrm{gm}$ of air-dried powder was taken in $100 \mathrm{ml}$ of each solvent (methanol, ethyl acetate, hexane, benzene, chloroform) in a conical flask, plugged with cotton wool and then kept on a rotary shaker. After 24 hours the supernatant was collected and the solvent was evaporated.

\section{Phytochemical studies:}

The methods described by Harborne were used to test for the presence of the active ingredients in the test sample ${ }^{17}$

\section{Test for steroids:}

A $10 \mathrm{ml}$ of plant extract (methanol, ethyl acetate, hexane, benzene, chloroform) was evaporated to a dry mass and the mass is dissolved in $0.5 \mathrm{ml}$ of chloroform. Acetic anhydride $[0.5 \mathrm{ml}]$ and $2 \mathrm{ml}$ of concentrated sulphuric acid were added to above ${ }^{18}$

\section{Test for alkaloids:}

The plant extract (methanol, ethyl acetate, hexane, benzene, chloroform) $[0.5 \mathrm{~g}]$ was stirred with $5 \mathrm{ml}$ of $1 \% \mathrm{HCl}$ on a steam bath. The solution obtained was filtered and $1 \mathrm{ml}$ of the filtrate was treated with two drops of Mayer's reagent. The two solutions were mixed and made up to $100 \mathrm{ml}$ with distilled water ${ }^{19,20}$

\section{Test for tannins:}

About $1 \mathrm{~g}$ of plant extract powder was weighed into a beaker and $10 \mathrm{ml}$ of distilled water added. The mixture was boiled for five minutes. Two drops of $5 \% \mathrm{FeCl}_{3}$ were then added ${ }^{\mathbf{2 1}}$.

\section{Test for flavonoids:}

A few drops of $1 \% \mathrm{NH}_{3}$ solution is added to the plant extract $[0.5 \mathrm{~g}]$ in a tube for observation of Yellow coloration $^{17}$

\section{Test for reducing sugar:}

To $0.5 \mathrm{ml}$ of extract solution, $1 \mathrm{ml}$ of water and $5-8$ drops of Fehling's solution were added at hot and observed for brick red precipitate ${ }^{17}$

\section{Hemolytic activity:}

In vitro hemolytic activity was performed by spectrophotometer method (Yang et al., 2005). A volume of $0.2 \mathrm{ml}$ of the blood suspension was mixed with $0.8 \mathrm{ml}$ of the plant extracts $(300 \mu \mathrm{g} / \mathrm{ml}, 150 \mu \mathrm{g} / \mathrm{ml}$, $75 \mu \mathrm{g} / \mathrm{ml}, 25 \mu \mathrm{g} / \mathrm{ml}$ ) concentrations in DMSO (Dimethyl solfoxide). The mixtures were incubated for 30 $\min$ at $37^{\circ} \mathrm{C}$ in a incubator. The mixture was centrifuged at $1500 \mathrm{rpm}$ for $10 \mathrm{~min}$ in a laboratory centrifuge. The free hemoglobin in the supernatant was measured in UV-Vis spectrophotometer at $540 \mathrm{~nm}$. Phosphate buffer saline and distilled water were used

as minimal and maximal hemolytic controls. Each experiment was performed in triplicates at each concentration. The level of percentage hemolysis by the extracts was calculated according to the following formula:

$$
\% \text { Hemolysis }=\quad \frac{A_{t}-A_{n}}{A_{c}-A_{n}} \times 100
$$

Here: $A_{t}$ is the absorbance of test sample.

$A_{n}$ is absorbance of the control (saline control)

$A_{c}$ is the absorbance of the control (water control) 


\section{RESULTS AND DISCUSSION}

\section{Phytochemical estimation:}

The qualitative screening of phytoconstituents showed the presence of alkaloids, terpenoids, cardic glycosides, tanins, steroids, saponins and anthraquinones in both the ethyl acetate extracts of leaves of Croton bonplandianum (Table 1). Flavonides are present only in the ethyl acetate extract of Croton bonplandianum whereas the reducing sugars were not detected in either of the extracts of $J$. adhatoda. The results for the phytochemical investigations of Croton bonplandianum leaves are illustrated in Table 1.

Table 1: Display the presence/ absence of different phytochemicals in the leaf of Justicia adhatoda

\begin{tabular}{|l|l|l|l|}
\hline Phytochemicals & Ethyl acetate & Chloroform & Benzene \\
\hline Tannin & + & - & - \\
\hline Alkaloid & + & + & + \\
\hline Flavonoid & + & + & + \\
\hline Phenolic & - & - & - \\
\hline Steroid & + & + & + \\
\hline Saponin & + & + & + \\
\hline Reducing sugar & - & - & - \\
\hline
\end{tabular}

Since ancient time, plants products been utilized for the treatment of various health problems. Plants are one of the most important sources of drug discovery and development. The plant used in this study has been excessively used in traditional medicine to cure a variety of diseases. Croton bonplandianum is used to cure helminthic infection, diabetes, inflammation etc. Hemolytic activity of the Ethyl acetate, Benzene, chloroform extract of leaves Croton bonplandianum was screened against normal human erythrocytes. Hemolytic activity of the plant is expressed in percentage hemolysis. All the samples exhibited very low hemolytic effect toward human erythrocytes. However, these extracts showed dose dependant increase in hemolytic activity. The ethyl acetate extract of Croton bonplandianum exhibited the maximum hemololytic activity and ranked 1 in the list.

Some other plants also have been studied for the hemolytic activity towards humans or animal erythrocytes. Different solvent extracts of Syzigum cuminii seeds and Crateva nurvula bark were reported to possess no hemolytic effect on sheep erythrocytes (Mathur et al., 2011). Achyranthes aspera was reported to possess very low hemolytic activity towards human erythrocytes (Priya et al., 2010). Aqueous extract of Lantana camara and its various solvent fractions were reported to possess moderate hemolytic activity towards human erythrocytes (Kalita et al., 2011). Oliveira1 et al., 2009 screened the hemolytic activity of seventy one extracts from twelve plants. Only three extracts prepared from $E$. nuda showed significant hemolytic activity. Karanja oil from Pongamia glabra was reported to exhibite a dose dependent increase in the haemolysis towards the rabbit red blood cells (Gandhi and Cherian, 2000). Mukherjee and Rajasekaran (2010) reported the high hemolytic activity of the different solvent extracts of Allium stracheyi Baker towards human red blood cells. Chloroform and aqueous extract of leaves of Acanthus ilicifolius were reported to possess significant hemolytic activity towards the chick red blood cells (Thirunavukkarasu et al., 2011).
The results of this study conclude that the various extracts from the leaves of Croton bonplandianum are non/less toxic to the human erythrocytes.

Table 2: Hemolytic activity of Ethyl acetate extract of Croton bonplandianum against human erythrocytes

\begin{tabular}{|c|c|c|}
\hline Concentration $(\mu \mathrm{g} / \mathrm{ml})$ & OD value & $\begin{array}{c}\text { Percentage of } \\
\text { hemolysis }\end{array}$ \\
\hline 300 & 0.71 & 162.5 \\
\hline 150 & 0.89 & 137.5 \\
\hline 75 & 0.98 & 81.25 \\
\hline 25 & 1.02 & 31.2 \\
\hline
\end{tabular}

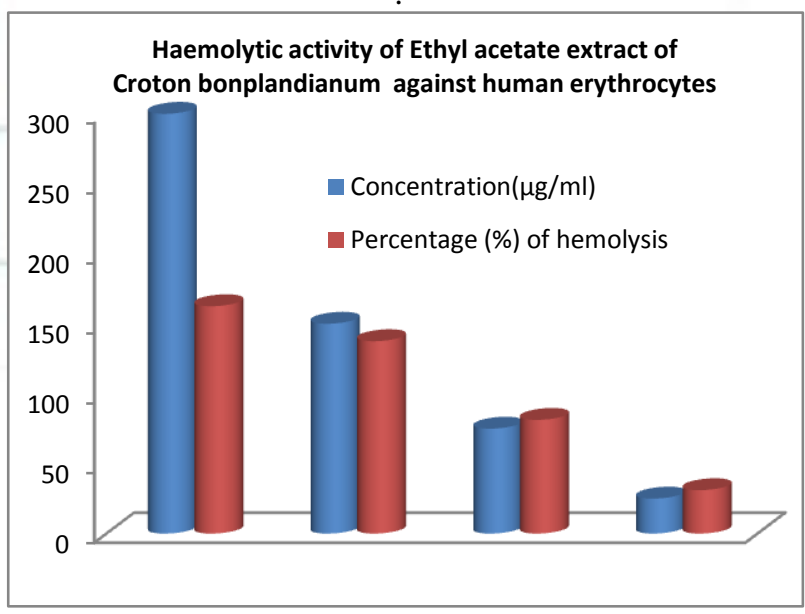

Figure 1: Haemolytic activity of Ethyl acetate extract of Croton bonplandianum against human erythrocytes

Table 3: Hemolytic activity of Benzene extract of Croton bonplandianum against human erythrocytes

\begin{tabular}{|c|c|c|}
\hline Concentration $(\mu \mathrm{g} / \mathrm{ml})$ & OD value & $\begin{array}{c}\text { Percentage of } \\
\text { hemolysis }\end{array}$ \\
\hline 300 & 0.59 & 131.5 \\
\hline 150 & 0.77 & 62.5 \\
\hline 75 & 0.86 & 37.5 \\
\hline 25 & 0.97 & 18.5 \\
\hline
\end{tabular}




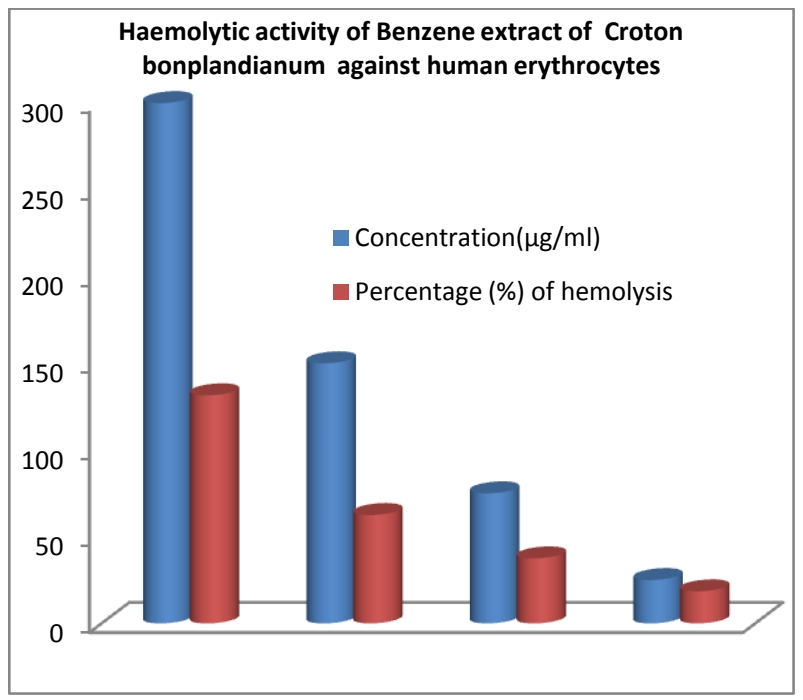

Figure 2: Haemolytic activity of Benzene extract of

Croton bonplandianum against human erythrocytes

Table 4: Hemolytic activity of Chloroform extract of Croton bonplandianum against human erythrocytes

\begin{tabular}{|c|c|c|}
\hline Concentration $(\mu \mathrm{g} / \mathrm{ml})$ & OD value & $\begin{array}{c}\text { Percentage of } \\
\text { hemolysis }\end{array}$ \\
\hline 300 & 0.38 & 156.25 \\
\hline 150 & 0.61 & 81.25 \\
\hline 75 & 0.89 & 43.2 \\
\hline 25 & 1.01 & 21.5 \\
\hline
\end{tabular}

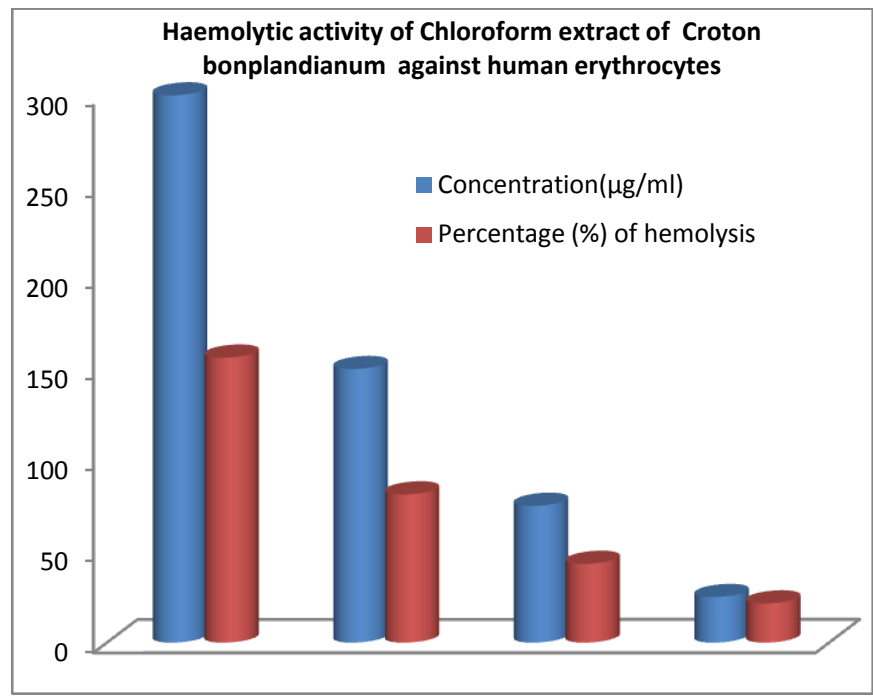

Figure 3: Haemolytic activity of Chloroform extract of

Croton bonplandianum against human erythrocytes

\section{In- details Hemolytic Activity of Ethyl Acetate extract of Croton bonplandianum:}

In this study, hemolytic activity of the Ethyl Acetate extract of leaves of Croton bonplandianum was screened against normal human erythrocytes. All the samples exhibited very low hemolytic effect toward human erythrocytes. However, these extracts showed dose dependant increase in hemolytic activity (Figure 1)

Table 5: Hemolytic Activity of Ethyl Acetate Extract of Croton bonplandianum against Human erythrocytes

\begin{tabular}{|c|c|c|c|c|}
\hline SL No. & Concentration $(\boldsymbol{\mu g} / \mathbf{m l})$ & Dilution & Absorbence (O.D) & Cell viability (\%) \\
\hline 1. & 300 & NEAT & 0.71 & 162.5 \\
\hline 2. & 150 & $1: 2$ & 0.89 & 137.5 \\
\hline 3. & 75 & $1: 4$ & 0.98 & 81.25 \\
\hline 4. & 25 & $1: 12$ & 1.02 & 31.2 \\
\hline 5. & Cell control & - & 0.76 & 200 \\
\hline
\end{tabular}

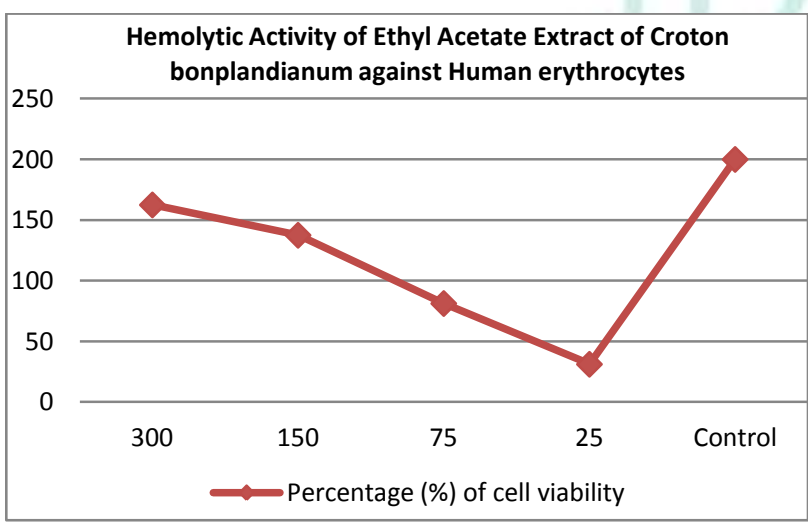

Figure 4: Hemolytic Activity of Ethyl Acetate Extract of Croton bonplandianum against Human erythrocytes

Four concentrations are reported in Table 5. The hemolytic activity of the different concentrations of Ethyl Acetate extracts was found in the following order: $200 \mu \mathrm{g} / \mathrm{ml}<100 \mu \mathrm{g} / \mathrm{ml}<50 \mu \mathrm{g} / \mathrm{ml}<25 \mu \mathrm{g} / \mathrm{ml}$ and we use Plot only Positive control of percentage of cell hemolysis in Figure no. 4.

\section{CONCLUSION}

Development of resistance by the microorganisms to chemotherapeutic agents appears to be a continuous process since the discovery of antibiotics. Scientists have realized an immense potential in natural products from medicinal plants to serve as an alternate source of combating infections in human beings which may also be of lower cost and lesser toxicity. We know that organisms are gaining resistance day by day towards the multi drug or antibiotics, so that some natural product should be try to overcome these antibiotic resistant organisms. Moreover the plant extract of Croton bonplandianum have less Hemolytic activity as it shown above That's why we can say that the Ethyl Acetate extract of Croton bonplandianum can be used for designing several drugs to treat complicated Infections in future. Further work on isolation and characterization of active antimicrobial compounds from medicinal plants and their pharmacodynamic study would be highly beneficial for the management of severe life threatening infections. 


\section{REFERENCES}

1. Blot SI, Depuydt P, Annemans L, Benoit D, Hoste E, De Waele JJ, et al. Clinical and economic outcomes in critically ill patients with nosocomial catheter-related bloodstream infections. Clinical Infectious Diseases. 2005; 41:1591-8.

2. Saeed S, Tariq P. Antibacterial activities of Mentha piperita, Pisum sativum and Momordica charantia. Pakistan Journal of Botany. 2005; 37:997.

3. Lam S, Chan H, LeRiche JC, Chan-Yeung M, Salari H. Release of leukotrienes in patients with bronchial asthma. Journal of allergy and clinical immunology. 1988; 81:711-7.

4. Grant EN, Lyttle CS, Weiss KB. The relation of socioeconomic factors and racial/ethnic differences in US asthma mortality. American journal of public health. 2000; 90:1923.

5. Ma Y, Aymeric L, Locher C, Mattarollo SR, Delahaye NF, Pereira P, et al. Contribution of IL-17-producing $\gamma \delta \mathrm{T}$ cells to the efficacy of anticancer chemotherapy. The Journal of experimental medicine. 2011; 208:491-503.

6. Poonkothai M, Saravanan M. Antibacterial activity of Aegle marmelos against leaf, bark and fruit extracts. Ancient science of life. 2008; 27:15.

7. Davis RJ. MAPKs: new JNK expands the group. Trends in biochemical sciences. 1994; 19:470-3.

8. Dick DM, Foroud T, Flury L, Bowman ES, Miller MJ, Rau NL, et al. Genomewide linkage analyses of bipolar disorder: a new sample of 250 pedigrees from the National Institute of Mental Health Genetics Initiative. The American Journal of Human Genetics. 2003; 73:107-14.

9. Burt S. Essential oils: their antimicrobial properties and potential application in foods-A review. International Journal of Food Microbiology. 2004, 94:223-253.

10. Pauli A, Amicbase. Essential Oils Supplementary Information: Review Science, 90513 Zirndorf, Further Str. 13.
11. Buchbauer G, Jirovetz L. Aromatherapy use of fragrances and essential oils as medicaments. Flav. Fragr. J. 1994, 9: 217 222.

12. Hussain A I, Anwar F, Sherazi S T H, Przybylski R. Chemical composition. Antioxidant and antimicrobial activities of basil (Ocimum basilicum) essential oils depends on seasonal variations. Food Chemistry. 2008; 108:986-995.

13. Mathur P. Kapil A. Das B., Dhawan B. Prevalence of ESBL producing gram negative bacteria in a tertiary care hospital. Indian J. Med. Res., 2002; 115:153-157.

14. Sharma S. Bhat G.K. and Shenoy S. Virulence factors and drug resistance in Escherichia coli isolated from extraintestinal infections. Indian J. Med. Microbiol., 2007; 25:369-373

15. Bahashwan S.A., El Shafey H.M. Antimicrobial resistance patterns of Proteus isolates from clinical specimens. Eur. Sci. J., 2013; 9:188-202.

16. Parekh, J. and Chanda, S. Antibacterial activity of aqueous and alcoholic extracts of 34 Indian medicinal plants.

17. Buchbauer G, Jirovetz L. Aromatherapy use of fragrances and essential oils as medicaments. Flav. Fragr. J. 1994, 9: 217 222.

18. Hussain A I, Anwar F, Sherazi S T H, Przybylski R. Chemical composition. Antioxidant and antimicrobial activities of basil (Ocimum basilicum) essential oils depends on seasonal variations. Food Chemistry. 2008, 108; 986-995.

19. Mathur P. Kapil A. Das B, Dhawan B. Prevalence of ESBL producing gram negative bacteria in a tertiary care hospital. Indian J. Med. Res., 2002; 115:153-157.

20. Sharma S. Bhat G.K. and Shenoy S. Virulence factors and drug resistance in Escherichia coli isolated from extraintestinal infections. Indian J. Med. Microbiol., 2007; 25:369-373.

21. Bahashwan S.A. and El Shafey H.M. Antimicrobial resistance patterns of Proteus isolates from clinical specimens. Eur. Sci. J., 2013; 9:188-202. 